\title{
Ecological and social outcomes of urbanization on regional farming systems: a global synthesis
}

\author{
Pramila Thapa $^{1}$, Mario Torralba ${ }^{1}$, Andreas Buerkert $^{2}$, Christoph Dittrich ${ }^{3}$ and Tobias Plieninger $^{1,4}$
}

\begin{abstract}
Though urban land covers only around $0.5 \%$ of the Earth's terrestrial surface, urbanization often leads to significant changes in land use and land cover. However, knowledge on the ecological and social outcomes of urbanization is largely fragmented across a multitude of local-level studies. We synthesized the outcomes of urbanization on 15 ecological and social variables associated with regional farming systems, namely water quality, agro-biodiversity, carbon sequestration, control of invasive species, soil fertility, control of soil erosion, pollination, cultural identity, food security, income and employment, demographic stability, conflict mitigation, social network, health and education, and equity. From 246 cases, positive, negative, and non-conclusive urbanization outcomes were extracted. Additionally, distributions of these outcomes by continent, population size of towns/cities, national per-capita GDP, and dominant farming systems were assessed. As a result, more negative than positive outcomes were found. Although ecological outcomes were largely negative, social ones were mostly positive. Threats to water quality, demographic stability, and cultural identity arose as particularly pressing issues. The ecological outcomes related to pollination were largely positive but all other ecological variables reported higher negative outcomes. The social outcomes related to the economic viability of farming and employment were largely positive, whereas those related to cultural and equity aspects were predominantly negative. The ecological outcomes were frequently negative in the Global South, medium-large cities, poor countries, and for livestock or fishery systems. The social outcomes were more frequently negative in the Americas, highly populated cities and megacities, wealthy countries, and for livestock and fishery systems. The threats and opportunities of rural-urban transformations in different dimensions and contexts of farming systems should be considered in any urban planning strategy.
\end{abstract}

Key Words: agriculture; evidence synthesis; social-ecological systems; sustainable urbanization

\section{INTRODUCTION}

Urban areas are complex social-ecological systems that comprise diverse sets of built environments, flora and fauna, economic activities, and cultural aspects (Ye et al. 2018). At least 55\% of the world's population live in urban areas, and this percentage is predicted to rise to $68 \%$ by 2050 (United Nations 2018). Although the global population growth rate has slowed down compared to previous years, urbanization continues to increase substantially (Seto et al. 2011). Urbanization is defined as an increase in the share of the urban population to the total population over time (Satterthwaite et al. 2010). It is accompanied by an accumulation or expansion of built-up areas (Beauchemin and Bocquier 2004). Because agriculture is necessary to fulfil basic human needs, e.g., food security, there is a growing interest in maintaining farming systems in an urbanizing world (Seto and Ramankutty 2016). Although urbanization can have telecoupled effects on farming systems across the world, the most direct effects are typically felt on a regional scale in urban hinterlands, those of urbanizationdriven farmland loss (Seto and Ramankutty 2016). Most notably, many farmlands are converted to built-up lands in the urbanization process, and this is one of the least reversible human activities (Seto and Reenberg 2014). Accordingly, the United Nations Sustainable Development Goal to strive for "Sustainable Cities and Communities" is a grand societal challenge (United Nations 2017). In this context, urban green infrastructure (UGI) has been introduced as a spatial planning concept to contribute to sustainable urban development. Although it has been seldom considered thus far, the integration of semi-natural farmlands into UGI planning may provide pathways to minimize farmland loss in the urbanization process (Rolf et al. 2020).

In the last five decades, an intensive and rapid spatial and demographic expansion of urban regions has been accompanied by far-reaching worldwide socio-spatial transformations (Hoffmann et al. 2017). The transformations have reconfigured the "hinterlands," and heterogeneous "urban landscapes' have emerged. At least $1.8 \%$ of global cropland is projected to be lost to urban expansion by 2030 , and $80 \%$ of these losses are predicted to take place in Asia and Africa. As most urban expansion replaces fertile arable land (Bren d'Amour et al. 2017), agriculture-dependent communities give up farming and shift toward off/non-farm activities. Urbanization also creates competition over the use of resources (e.g., land, water, labor) near or within cities. Land fragmentation, land use, land cover changes, and abandonment of the farming profession are a few examples of the consequences of urbanization for farming systems (Seto and Ramankutty 2016).

The dynamics of urbanization vary considerably between world regions. Although Europe and North and South America have been intensely urbanized since the early 20th century, urbanization in Asia and Africa has taken on faster momentum since the 1970s (Nagendra 2018), which has not slowed down to date (Cugurullo 2016). Urbanization in the Global North is mostly driven by GDP growth, and in the Global South it is determined by urban population growth rates (Seto et al. 2011). The share of urban populations to total populations is $40 \%$ in

${ }^{1}$ Social-Ecological Interactions in Agricultural Systems Group, Faculty of Organic Agricultural Sciences, University of Kassel, Witzenhausen, Germany, ${ }^{2}$ Organic Plant Production and Agroecosystems Research in the Tropics and Subtropics, Organic Agricultural Sciences (FB11), University of Kassel, Witzenhausen, Germany, ${ }^{3}$ Institute of Human Geography, University of Goettingen, Germany, ${ }^{4}$ Department of Agricultural Economics and Rural Development, University of Goettingen, Germany 
Africa, $48 \%$ in Asia, $73 \%$ in Europe, $80 \%$ in Latin America, and $81 \%$ in North America (United Nations 2014). Commonly, in low- and middle-income countries, urbanization proceeds informally, haphazardly, and largely without plans (Satterthwaite et al. 2010). Rapid rates of urbanization are observed and forecasted for the Global South, mainly for China, India, and Nigeria (United Nations 2014). China displays the highest rate of urban expansion $(7.5 \%$ per year), while India shows $4.8 \%$ and Africa averages 4.3\%; in Oceania, Europe, and the Americas, rates of urban expansion are currently decreasing, but conversion from rural to urban lands remains a major process (Seto et al. 2011). Though urban land covers only approximately $0.5 \%$ of the Earth's terrestrial surface (Zhou et al. 2015), urbanization causes significant changes in land use and land cover through the conversion of natural or semi-natural ecosystems to urban ecosystems (Ye et al. 2018).

Urbanization processes often affect ecological aspects of farming systems (Satterthwaite et al. 2010). For instance, in Nepal, India, and Bangladesh, urbanization has led to the pollution of rivers by urban discharge (Karn and Harada 2001). The water has become unfit for drinking, irrigation, and other social and cultural events. Similarly, arable soils have decreased under urbanization, which has ultimately reduced the soil's organic carbon pool, increased $\mathrm{CO}_{2}$ emissions (Abu-hashim et al. 2016), and reduced soil fertility (Zhai et al. 2017). Food and fodder production have also decreased (Derkzen et al. 2017).

Urbanization also has implications on the social aspects of farming. Most urban dwellers work in industrial or service sectors; therefore, less food is produced than is consumed in urban areas. Given that most poor urban dwellers have low and irregular earnings and their access to farm produce is limited, they are more vulnerable to food insecurity than the rural poor (Tacoli 2017). Among wealthy urban dwellers, part-time, hobby, and retirement farming practices are becoming more common than professional farming, while social farming has become trendier in the urban periphery. This change reduced the number of both full-time farmers and land-owners that actually farm (Primdahl et al. 2013). Urbanization also exerts strong, indirect influences on farmers' livelihoods in the hinterlands (Zasada 2011). It increases demand for food and food-based products in urban areas, which may present opportunities for farmers and other actors across the food value chains (Hatab et al. 2019). Urbanization is generally accompanied by increasing wealth levels, but the distribution of this economic wealth is often unequal (Davis and Henderson 2003). Access to the job market is different for men and women in cities because of unequal socio-cultural structures; opportunities for women are often lacking (Sen 2017). Therefore, urbanization profoundly influences land use and the social systems of the communities that are in or near urban agglomerations (Busck et al. 2006).

Understanding and managing the impacts of urbanization on farming is central to achieving the Sustainable Development Goals, but this theme has received relatively little scholarly attention thus far, except for some overview studies on the impacts of urbanization on natural lands, agriculture, and food systems (e.g., Satterthwaite et al. 2010, Bren d'Amour et al. 2017, van Vliet 2019). Accordingly, empirical evidence on the multiple outcomes of urbanization on farming systems is fragmented across individual study sites (Su et al. 2014). Interdisciplinary studies that integrate ecological and social outcomes of urbanization are rare (van Vliet et al. 2015). Therefore, we explored the ecological and social outcomes of urbanization on regional farming systems based on a systematic review of the scientific literature. Our study was guided by the following research questions:

1. What are the positive and negative ecological outcomes of urbanization on regional farming systems, such as soil fertility, soil erosion, water quality, agro-biodiversity, carbon sequestration, pollination, and invasive species?

2. What are the positive and negative social outcomes of urbanization on regional farming systems, such as income and employment, food security, health and education, social networks, equity, demographic stability, conflict, and cultural identity?

3. How are these outcomes explained by potential explanatory variables, such as continent, population size of cities/towns, national annual per-capita GDP, and dominant farming systems?

\section{METHODS}

\section{Approach}

Systematic reviews gather relevant existing scientific literature to validate and upscale insights and identify potential gaps and biases (Pullin and Knight 2009). A wide range of synthesis techniques are available to generate global knowledge from local case studies (Magliocca et al. 2015). This review was inspired by previous global and continental reviews of land change processes and outcomes (van Vliet et al. 2012, Plieninger et al. 2016, Vang Rasmussen et al. 2018). Prior to the development of the review, we designed a protocol following the Preferred Reporting Items for Systematic Reviews and Meta-Analyses (PRISMA) standards (Moher et al. 2015; Fig. 1).

Fig. 1. Flow diagram summarizing the number of studies included and excluded from the synthesis in the screening process.

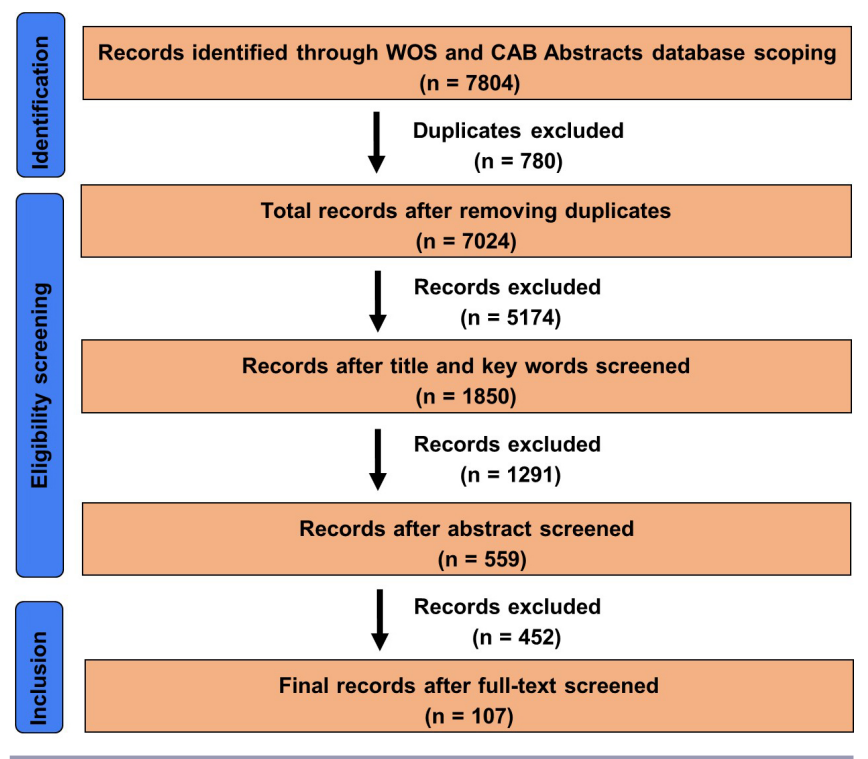




\section{Study selection}

To find and select relevant literature, we performed a scoping exercise in which we tested different combinations of search terms. Our final search strings provided a balance between being inclusive and remaining focused. We combined three types of search strings related to:

1. farming: "agricult*" OR "farm*" (Opitz et al. 2016);

2. urbanization: "urban*" (Opitz et al. 2016); and

3. outcome variables: "carbon sequestration" OR "soil fertility" OR "soil erosion" OR "water qualit*" OR "agr* bio*diversity" OR "invasive species" OR "pollinat*" OR "income" OR "labo*r demand" OR "food security" OR "health" OR "education" OR "demograph* stability” OR "equity” OR "social network*” OR "cultural identity" OR "conflict*".

We combined these strings to search for titles, keywords, and abstracts on the Web of Science (resulting in 4556 hits) and CAB Abstracts (resulting in 3248 hits) databases on 4 February 2019. After removing duplicates from both databases, 7024 papers remained. The idea of our search strategy was to include both specialist agricultural science papers (in CAB Abstracts) and more general papers performed in multiple disciplinary contexts (in Web of Science). We considered only papers in English but did not restrict the date of publication of the papers.

We defined the following inclusion criteria, all of which had to be explicitly met by the studies to be selected:

1. the paper covered an area that was directly exposed to urban expansion (i.e., a rural or peri-urban or urban area in the immediate surrounding of a city);

2. the paper was based on empirical field data, measuring at least one ecological or social outcome of urbanization on farming systems;

3. the paper provided new results not presented in another paper; and

4. the paper measured outcomes up to a regional level, within a maximum radius of $100 \mathrm{~km}$ around an expanding city.

We selected the papers in three steps for the final analysis (Fig. 1). In the first step, we discarded any paper that directly violated our inclusion criteria in its title and keywords, retaining 1850 papers for the next step. In the second step, the abstracts of the retained papers were reviewed and evaluated using the same inclusion criteria, leaving 559 papers. In the last step, we reviewed the full text, and 107 papers were finally selected. Cohen's Kappa index (Cohen 1960) was calculated to reduce bias and assess the level of agreement. For that, the first two authors of this manuscript read the same set of $10 \%$ of the papers. We calculated a Cohen's Kappa index of 0.84 , indicating a high level of agreement and minimum bias in the selection process. Thus, we proceeded with the selected 107 papers for data extraction and analysis.

\section{Data extraction and analysis}

We focused on two categories of urbanization outcomes on regional farming systems: ecological and social outcomes. We explored several classification frameworks and decided on an adapted version of the framework developed by van Vliet et al. (2012). Its 15 outcome variables provide a comprehensive and meaningful framework for the analysis of multiple ecological and social outcomes (Table 1). The ecological category comprised the following outcome variables: water quality, agro-biodiversity, control of invasive species, carbon sequestration, soil fertility, control of soil erosion, and pollination. The social category comprised income and employment, food security, equity, social networks, demographic stability, conflict mitigation, cultural identity, and health and education. We also considered the following four potential influencing variables to explain the ecological and social outcomes of urbanization on the regional farming systems: continent, population size, per-capita gross domestic product (GDP), and dominant farming system (Table 2).

Because the studies covered different types of urbanization outcomes and used a variety of indicators and metrics, we classified the direction of outcomes measured for each variable into positive, negative, or non-conclusive. Any desirable outcomes in the regional farming systems from the perspective of the respective author was considered a "positive outcome"; when the outcome was unwanted/undesirable, then it was recorded as a "negative outcome." If an outcome was not well-concluded, whether it was positive or negative or concluded as no or a confusing outcome, then it was considered a "non-conclusive outcome." The two first authors went through the same set of $21 \%$ of the selected papers to reduce potential bias in the outcome interpretation. We calculated a Kappa index of 0.97 , signaling a high agreement between the two authors, i.e., if the first author recorded a positive outcome on a certain paper, then so did the second author. If a paper reported on work that had been performed at more than one site or covered more than one outcome, we recorded each outcome as a separate case. For example, in a paper by Davivongs et al. (2012), the authors reported a positive outcome on "income and employment" but negative outcomes on "conflict mitigation" and "equity." Thus, we recorded three cases from this paper. We uploaded 246 cases from 107 papers on the Zenodo repository (http://doi. org/10.5281/zenodo.3974027). The strength of evidence of each case was assessed using a five-point scale (Table 3 ). We analyzed our data using descriptive statistics and cross-tabulations to assess the outcomes of urbanization on regional farming systems.

We applied a two-tailed Fisher's exact test, separately for each category of outcomes and within each category for each explanatory variable (continent, population size, national annual per-capita GDP level, and dominant farming system) to examine if the outcomes were significantly negative or positive. For example, out of 72 (excluding three non-conclusive) ecological cases, 48 cases reported negative outcomes, and the remaining 24 reported positive outcomes. Then, we applied Fisher's exact test to examine if the 48 negative outcomes were statistically higher or lower than the positive outcomes. We used a reference distribution of 36 negative and 36 positive cases (half of the sum of positive and negative ecological cases). We repeated the same steps for social outcomes and then for all explanatory variables and changed the reference distributions accordingly for each test. We reported the p-value and the odds ratio, i.e., the ratio of negative to positive results in our case. We extracted the odds ratio and p-values from Fisher's exact test. An odds ratio higher than 
Table 1. Outcome variables, their definitions, and the sources of their definitions

\begin{tabular}{|c|c|c|}
\hline Outcome variable & Definition & Sources \\
\hline Water quality & $\begin{array}{l}\text { Improvement or impoverishment of physical, biological, and chemical properties of } \\
\text { irrigating (surface or ground) water or water for aquaculture }\end{array}$ & $\begin{array}{l}\text { (Amoah et al. 2005, Arivarasi and } \\
\text { Ganesan 2017) }\end{array}$ \\
\hline Agro-biodiversity & Increase or decrease in varieties of cultivated flora or fauna either in land or water & (Wood and Lenné 1999) \\
\hline Control of invasive species & $\begin{array}{l}\text { Improvement or impoverishment of non-native invasive plants or animals in agricultural } \\
\text { system }\end{array}$ & (Aronson et al. 2007) \\
\hline Carbon sequestration & $\begin{array}{l}\text { Improvement or impoverishment in atmospheric } \mathrm{CO}_{2} \text { fixation into agricultural soil or } \\
\text { water }\end{array}$ & (Townsend-Small and Czimczik 2010) \\
\hline Soil fertility & $\begin{array}{l}\text { Improvement or impoverishment of soil micro or macro nutrients that promote growth } \\
\text { of agricultural plants, diversity and community of soil biota, and soil structure }\end{array}$ & (Mäder et al. 2002) \\
\hline Control of soil erosion & $\begin{array}{l}\text { Increase or decrease of removal of soil particles from agricultural soil due to flood or } \\
\text { wind or human activities }\end{array}$ & (Patel and Kathwas 2012) \\
\hline Pollination & $\begin{array}{l}\text { Improvement or impoverishment of pollen transfer by an insect (e.g., bee) between or } \\
\text { among flowers in a farmland }\end{array}$ & (McGregor 1976) \\
\hline Income and employment & $\begin{array}{l}\text { Increase or decrease in household farm or off-farm income of a farmer/farming } \\
\text { community (income); } \\
\text { increase or decrease in demand for labor in a farming community (employment/labor } \\
\text { demand) }\end{array}$ & $\begin{array}{l}\text { (Income: Rao and Qaim 2011; } \\
\text { employment: Petrick and Zier 2012) }\end{array}$ \\
\hline Food security & $\begin{array}{l}\text { Improvement or impoverishment of type, quality, or quantity of food intake of a } \\
\text { farming household }\end{array}$ & (FAO 2006) \\
\hline Equity & $\begin{array}{l}\text { Improvement or impoverishment of justice or social inclusion, e.g., in job market, } \\
\text { among farmers in terms of gender, age, ethnicity, access to land }\end{array}$ & (Uprety 1970) \\
\hline Social networks & $\begin{array}{l}\text { Improvement or impoverishment of open-ended interactions between agriculture's } \\
\text { various stakeholders, including for example farmers, merchants, extension agents, } \\
\text { scientists, and government officials }\end{array}$ & (Wood et al. 2014) \\
\hline Demographic stability & $\begin{array}{l}\text { Increase or decrease in out-migration, fertility, and mortality rates within farming } \\
\text { community }\end{array}$ & (Geist and Lambin 2002) \\
\hline Conflict mitigation & $\begin{array}{l}\text { Improvement or impoverishment of misunderstanding/non-transparency in farming } \\
\text { communities for the use of public/common pool goods or services }\end{array}$ & (Turner 2004) \\
\hline Cultural identity & $\begin{array}{l}\text { Improvement or impoverishment of direct or indirect interactions of farming } \\
\text { community to their environment for their interactions or symbolic meaning }\end{array}$ & (Hall 2014) \\
\hline Health and education & $\begin{array}{l}\text { Improvement or impoverishment in physical health, health facilities, education levels, } \\
\text { and education facilities among farmers }\end{array}$ & (Tong et al. 2017) \\
\hline
\end{tabular}

Table 2. Explanatory variables, their definitions, and their sources of data extraction

\begin{tabular}{|c|c|c|}
\hline $\begin{array}{l}\text { Explanatory } \\
\text { variables }\end{array}$ & Description & Source \\
\hline Continent & $\begin{array}{l}\text { The continent in which the case study } \\
\text { site is located (Africa, Asia, Europe, } \\
\text { Latin America, North America, and } \\
\text { Oceania) }\end{array}$ & Respective study \\
\hline $\begin{array}{l}\text { Population } \\
\text { size }\end{array}$ & $\begin{array}{l}\text { Total number of humans currently } \\
\text { living in a city or a town (the case } \\
\text { study site) } \\
\text { Unit: Count of persons } \\
\text { Scale: City/Town level (2018) }\end{array}$ & City Population \\
\hline $\begin{array}{l}\text { Per-capita } \\
\text { GDP }\end{array}$ & $\begin{array}{l}\text { The sum of gross value added by all } \\
\text { resident producers in the economy } \\
\text { plus any product taxes and minus any } \\
\text { subsidies not included in the value of } \\
\text { the products. } \\
\text { Unit: US Dollar (\$) } \\
\text { Scale: National level (2018) }\end{array}$ & World Bank \\
\hline $\begin{array}{l}\text { Dominant } \\
\text { farming } \\
\text { system }\end{array}$ & $\begin{array}{l}\text { The main farming system in the case } \\
\text { study site (vegetable crops, annual } \\
\text { crops, perennial crops, livestock or } \\
\text { fishery) } \\
\text { Scale: Case level }\end{array}$ & $\begin{array}{l}\text { Respective study; } \\
\text { World Program } \\
\text { for the Census of } \\
\text { Agriculture }\end{array}$ \\
\hline
\end{tabular}

Table 3. Strength of evidence of an outcome presented in a case and its interpretation

\begin{tabular}{|c|c|}
\hline $\begin{array}{l}\text { Strength of } \\
\text { evidence }\end{array}$ & Interpretation \\
\hline 5 & $\begin{array}{l}\text { The methods used to assess the impacts are explained in the } \\
\text { methods section and the analyses of the results are presented. } \\
\text { Reader can get the same conclusions based on the results and } \\
\text { could replicate the study based on the methods. }\end{array}$ \\
\hline 4 & $\begin{array}{l}\text { Methods are explained and results shown but some of the } \\
\text { results are not explained. Some of the conclusions do not } \\
\text { match the results. }\end{array}$ \\
\hline 3 & $\begin{array}{l}\text { The methods used are explained but certain aspects necessary } \\
\text { for the replication of the study (e.g., sample, the study area } \\
\text { boundaries, etc.) are not provided. Reader could not totally } \\
\text { replicate the study if s/he wanted. }\end{array}$ \\
\hline 2 & $\begin{array}{l}\text { The results are presented and discussed but the methods on } \\
\text { how they get these results are not explained or vice-versa. } \\
\text { Reader does not know how the authors got the results. }\end{array}$ \\
\hline 1 & $\begin{array}{l}\text { The impacts are described in the discussion but not explained } \\
\text { in the results and the methods used were not explained. } \\
\text { Basically, reader does not know how the authors get the } \\
\text { conclusions. }\end{array}$ \\
\hline
\end{tabular}

one means that negative outcomes were higher than positive ones. Fisher's exact test is recommended when the number of counts for the analysis is small (Bower 2003). In our study, the number of positive or negative counts were small for some variables. Thus, we used Fisher's exact test for consistency of analysis. We performed the analysis using Microsoft Excel and statistical software R version 3.6.1 (2019-07-05) for Windows. 
Fig. 2. Geographical overview of the cases and their reported directions of the ecological or social outcomes of urbanization (non-conclusive cases $[n=9$, with 3 ecological and 6 social outcomes] are not presented).

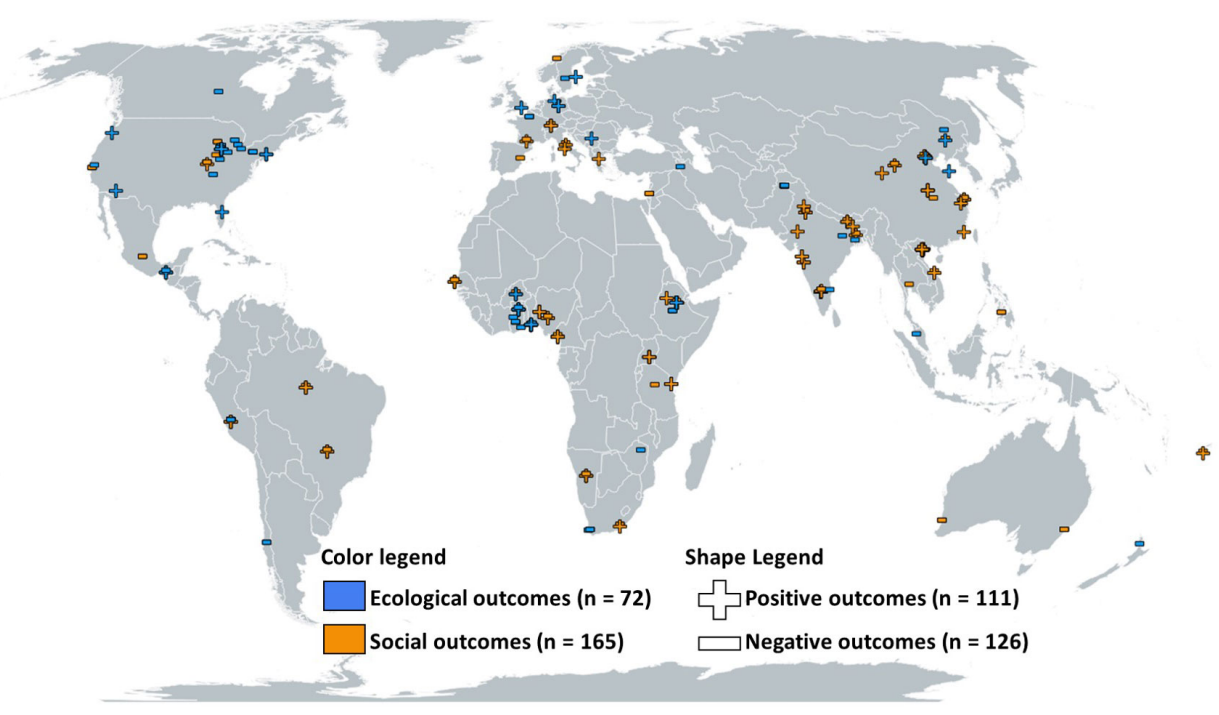

\section{RESULTS}

General trends regarding outcomes of urbanization

Overall, the observed ecological variables were less frequently studied than social variables (Fig. 2). More negative than positive outcomes of urbanization on regional farming systems were reported. As shown in Table 4, the likelihood of obtaining negative ecological outcomes on regional farming was statistically twice as high as positive ecological outcomes (odds ratio $=1.99$, $\mathrm{p}$-value $=0.06$ ).

Table 4. The results of Fisher's exact tests for overall ecological and social outcomes excluding non-conclusive outcomes. The odds ratio is the odds of getting negative outcomes compared to the positive outcomes. $*$ Outcomes are statistically significant at $\mathrm{p}<$ or $=0.1$

\begin{tabular}{lll}
\hline \hline Outcome & Odds ratio & P-value \\
\hline Ecological & 1.99 & $0.06^{*}$ \\
Social & 0.90 & 0.66 \\
\hline
\end{tabular}

Among ecological variables, soil fertility $(n=5)$, control of soil erosion $(n=6)$, control of invasive species $(n=7)$, and carbon sequestration $(n=7)$ were among the least studied, whereas water quality $(\mathrm{n}=18)$, pollination $(\mathrm{n}=16)$, and agro-biodiversity $(\mathrm{n}=$ 16) were more widely studied. Negative outcomes were frequently reported for invasive species $(100 \%)$, water quality $(83 \%)$, soil fertility $(80 \%)$, soil erosion $(67 \%)$, and carbon sequestration $(57 \%)$. In contrast, pollination was reported with more positive outcomes (Fig. 3).

For social variables, there were more positive than negative outcomes, but the difference was statistically non-significant (Table 4). Social networks $(n=9)$ were the least studied social variable, whereas income and employment $(n=43)$, equity $(n=$ $32)$, and conflict mitigation $(n=28)$ were more widely studied.
More positive than negative social outcomes were found for income and employment (84\%), social networks (78\%), and health and education (61\%; Fig. 3). Negative outcomes dominated for demographic stability $(93 \%)$, cultural identity (73\%), conflict mitigation $(64 \%)$, and equity $(59 \%)$. The outcomes of urbanization on the social category of the regional farming system were not clear with the possibility of having almost equal positive and negative outcomes (odds ratio $=0.90, \mathrm{p}$-value $=0.66$ ).

Fig. 3. Ecological and social outcomes of urbanization on regional farming systems $(\mathrm{N}=$ number of cases per outcome variable). Bars on the right indicate the average strength of evidence; each bar represent one point of strength (interpreted in Table 3).

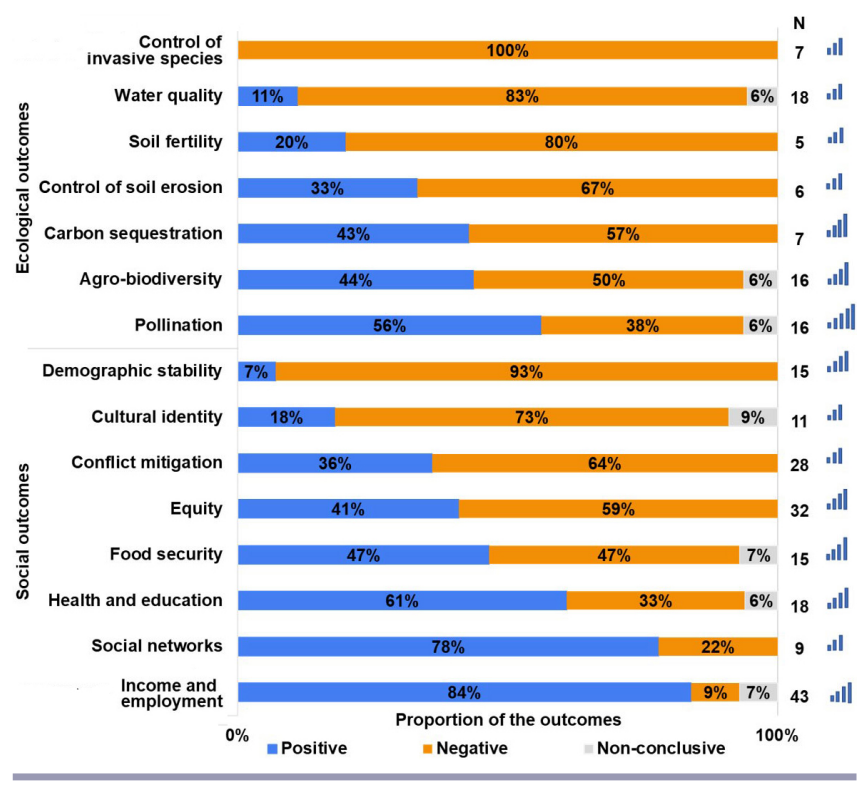


Table 5. The results of Fisher's exact tests for the distribution outcomes of urbanization among explanatory variables excluding nonconclusive outcomes. The odds ratio is the likelihood of getting negative outcomes compared to the positive outcomes. ** Outcomes are statistically significant at $\mathrm{p}<$ or $=0.05$; ${ }^{*}$ Outcomes are statistically significant at $\mathrm{p}<$ or $=0.1$; $^{\dagger}$ Fisher test is not reported for ecological outcomes because of too small sample size $(n=1)$

\begin{tabular}{|c|c|c|c|c|c|}
\hline \multirow[t]{2}{*}{ Explanatory variable } & \multirow{2}{*}{$\begin{array}{l}\text { Classes/levels of the explanatory } \\
\text { variable }\end{array}$} & \multicolumn{2}{|c|}{ Ecological outcomes } & \multicolumn{2}{|c|}{ Social outcomes } \\
\hline & & Odds ratio & P-value & Odds ratio & $\mathrm{P}$-value \\
\hline \multirow[t]{6}{*}{ Continent } & Africa & 3.62 & $0.09^{*}$ & 0.47 & $0.10^{*}$ \\
\hline & Asia & 2.86 & 0.40 & 0.77 & 0.49 \\
\hline & North America & 1.76 & 0.39 & 8.02 & 0.14 \\
\hline & Europe & 0.31 & 0.33 & 1.00 & 1.00 \\
\hline & South America & 4.34 & 0.54 & 1.69 & 0.52 \\
\hline & Oceania $^{\dagger}$ & - & - & 5.31 & 0.28 \\
\hline \multirow[t]{4}{*}{ Population size of the town/city } & Smaller than 100,000 & 1.57 & 0.69 & 0.87 & 0.73 \\
\hline & $100,000-1,000,000$ & 4.34 & $0.05^{* *}$ & 0.93 & 1.00 \\
\hline & $1,000,001-10,000,000$ & 1.88 & 0.28 & 0.77 & 0.79 \\
\hline & Larger than $10,000,000$ & 0.43 & 0.61 & 1.32 & 1.00 \\
\hline \multirow[t]{4}{*}{ National per-capita GDP level (US\$) } & Lower than 3000 & 4.34 & $0.05 * *$ & 0.46 & $0.02 * *$ \\
\hline & $3000-10,000$ & 1.57 & 0.69 & 1.32 & 0.58 \\
\hline & $10,001-50,000$ & 1.20 & 1.00 & 1.00 & 1.00 \\
\hline & Higher than 50,000 & 1.59 & 0.58 & 5.10 & $0.04 * *$ \\
\hline \multirow[t]{4}{*}{ Dominant farming system } & Vegetable crops & 1.98 & 0.38 & 1.00 & 1.00 \\
\hline & Annual crops & 1.61 & 0.53 & 0.81 & 0.56 \\
\hline & Perennial & 1.14 & 1.00 & 0.52 & 0.68 \\
\hline & Livestock or fishery & 9.91 & $0.06^{*}$ & 1.44 & 0.59 \\
\hline
\end{tabular}

\section{Outcome distribution by continent}

As shown in Figure 2, most of the cases were observed in countries of the Global South, mostly in Asia $(n=82$, with 13 ecological and 69 social cases) and in Africa ( $n=72$, with 19 ecological and 53 social cases). In the Global North, Europe ( $n=31$, with nine ecological and 12 social cases) was the region most extensively studied. South America ( $\mathrm{n}=25$, with six ecological and 19 social cases) and Oceania $(n=8$, with one ecological and seven social cases), including Australia, were comparatively less represented. Papers on large parts of North Africa, Russia, and Central Asia were missing, and we found only a relatively small number of cases in Oceania and South America.

Negative ecological outcomes were reported more frequently in all continents, except Europe (Fig. 4). The likelihood of observing negative ecological outcomes was almost four times higher than that for positive ecological outcomes in Africa (odds ratio $=3.62$, p-value $=0.09$; Table 5). In Europe, we observed that the odds of a negative ecological outcome were around one-third times lower than that for a positive outcome (odds ratio $=0.31, \mathrm{p}$-value $=$ 0.33 ), but the difference was statistically nonsignificant. In the case of Oceania, we recorded only one negative ecological outcome, and thus, we did not perform any statistical test.

The number of positive social outcomes outweighed negative ones in Africa and Asia (Fig. 4). In Oceania and the Americas, the frequency of negative social outcomes was higher. However, statistically interesting (or almost) significant results were observed only in Africa and North America. The likelihood of observing a negative social outcome in Africa was around half of that of a positive outcome (odds ratio $=0.47$; -value $=0.10$ ), whereas in North America it was eight times higher than that of a positive outcome (odds ratio $=8.02, \mathrm{p}$-value $=0.14$; Table 5).
Fig. 4. Ecological and social outcomes of urbanization on regional farming systems across continents (* Outcomes are statistically significant at $\mathrm{p}<$ or $=0.1$ ).

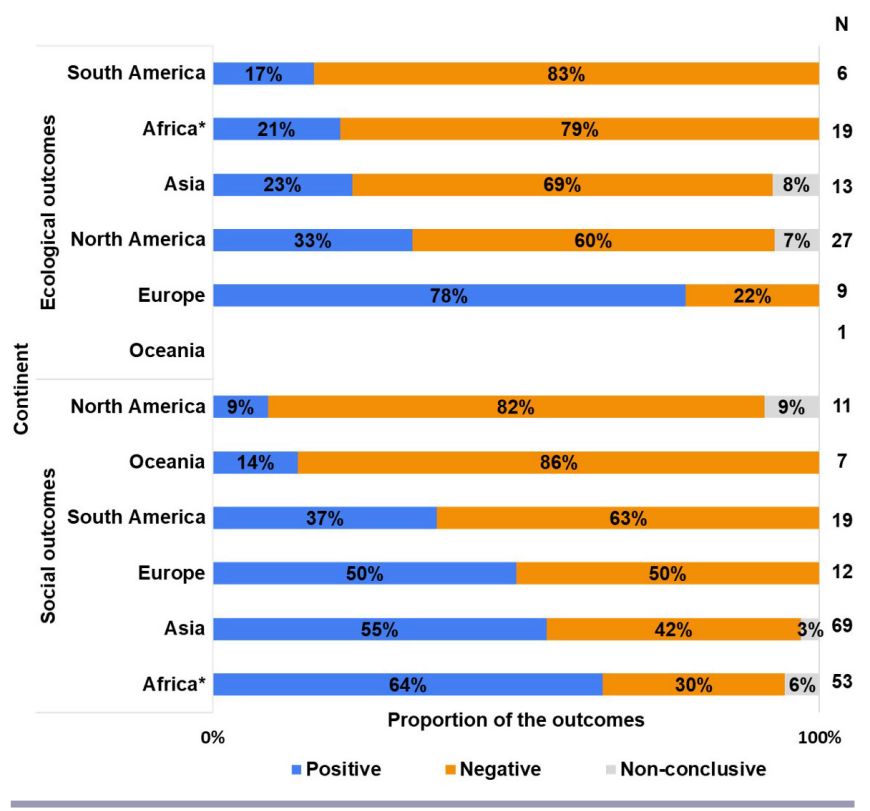

Outcome distribution by population size

As shown in Figure 5, the highest number of cases was reported from cities with a population size smaller than $100,000(n=85$, with 13 ecological and 72 social cases), and the lowest share originated from large cities with a population size larger than $10,000,000(n=21$, with seven ecological and 14 social cases $)$. 
Fig. 5. Ecological and social outcomes of urbanization on regional farming systems across population sizes of cities/towns $(* *$ Outcomes are statistically significant at $\mathrm{p}<$ or $=0.05)$.

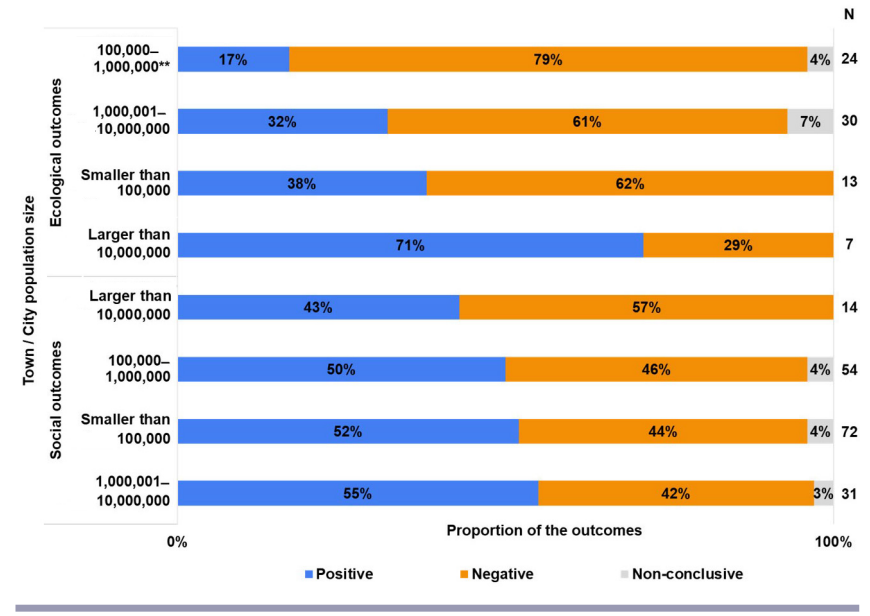

In all cities, except for those with populations higher than 10 million, the number of cases reporting the negative ecological outcomes of urbanization were higher. We observed four-fold higher cases with a negative ecological outcome than positive outcome in cities with a population of 100,000 to one million with statistical significance (odds ratio $=4.34, \mathrm{p}$-value $=0.05$; Table $5)$.

As for social outcomes, positive outcomes were reported in a higher number of cases for all cities/towns, except for cities with a population larger than 10 million (Fig. 5). However, across all four population size classes, the odds ratio values were around one. This indicates the equal likelihood of obtaining a positive or negative social outcome of urbanization in regional farming systems (Table 5).

\section{Outcome distribution by national annual per-capita GDP level}

As shown in Figure 6, the impacts of urbanization on regional farming systems were most frequently studied in the areas with national annual per-capita GDP less than US $\$ 3000(n=106$, with 22 ecological and 84 social cases) and least frequently in areas with a GDP between US\$10,001 and US\$50,000 $(n=20$, with 12 ecological and eight social cases).

We observed a higher number of cases reporting negative ecological outcomes (Fig. 6) in all GDP levels. In the areas with a GDP level lower than US\$3000, the likelihood of observing a negative ecological outcome was four times higher than that for positive outcomes with statistical significance (odds ratio $=4.34$, p-value $=0.05 ;$ Table 5).

As for the social impacts of urbanization, we observed a higher proportion of negative than positive outcomes for areas with percapita GDP levels higher than US\$50,000 and US\$3000-10,000, and a lower proportion of negative outcomes for areas with an income less than US\$3000 (Table 5). In areas with an annual percapita GDP level higher than US\$50,000, the likelihood of observing negative social outcomes was five times higher than achieving positive outcomes (odds ratio $=5.10, \mathrm{p}$-value $=0.04)$.
In contrast, in areas with a per-capita GDP level less than US\$3000, the likelihood of observing a negative outcome was around half compared to that for observing a positive outcome (odds ratio $=0.46$, $\mathrm{p}$-value $=0.02$ )

Fig. 6. Ecological and social outcomes of urbanization on regional farming systems across national annual per-capita GDP levels $(* *$ Outcomes are statistically significant at $\mathrm{p}<$ or $=$ $0.05)$.

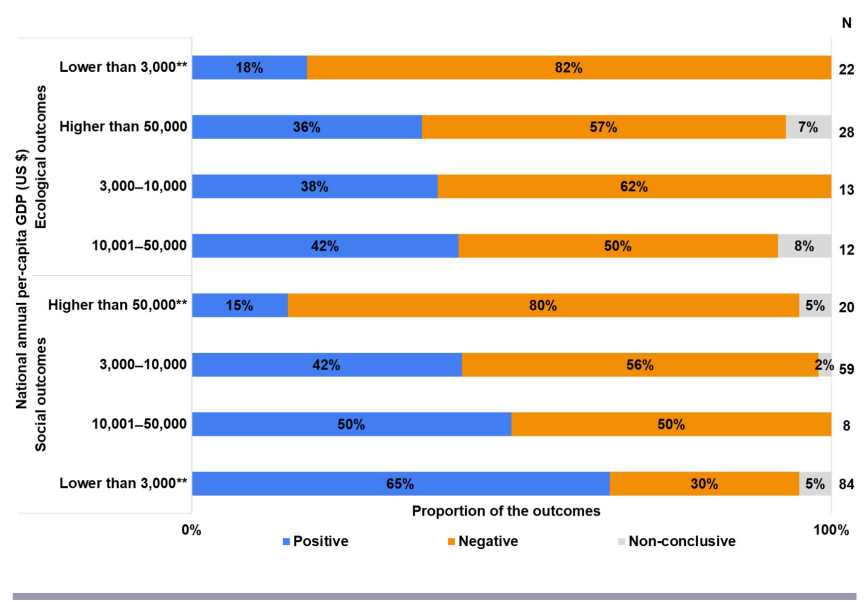

Outcome distribution by dominant farming system

We also categorized our results based on the dominant farming systems (Fig. 7). Our results showed that the highest number of cases were reported from areas dominated by annual cropping systems ( $n=122$, with 22 ecological and 100 social cases) and the lowest number of cases originated from areas with perennial crops ( $n=28$, with 16 ecological and 12 social cases).

Fig. 7. Ecological and social outcomes of urbanization on regional farming systems across dominant farming systems (* Outcomes are statistically significant at $\mathrm{p}<$ or $=0.1$ ).

N

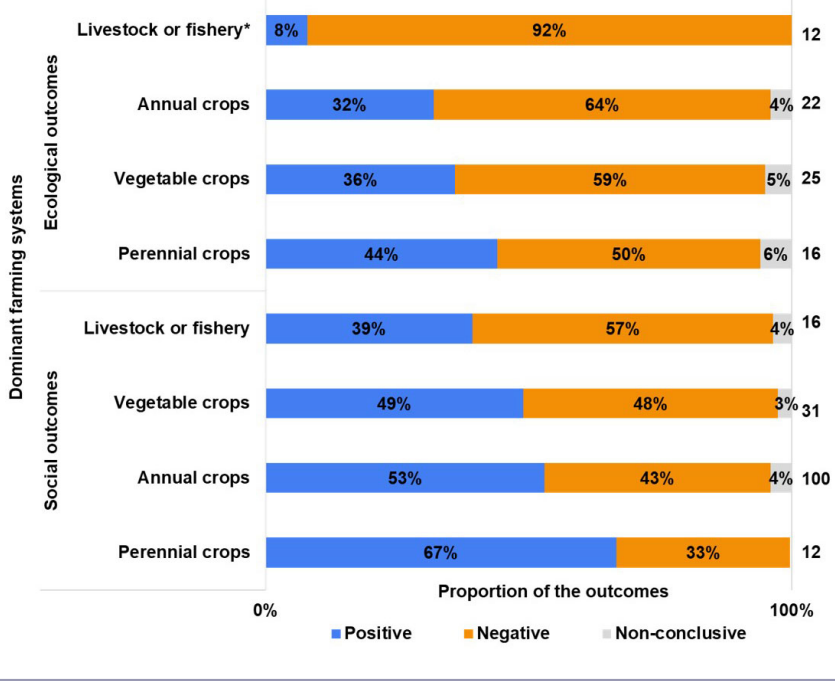


In most types of farming systems (exception: perennial crops), a higher number of cases reported negative ecological outcomes of urbanization. In areas dominated by perennial crops, an almost equal number of cases reported positive and negative outcomes (odds ratio $=1.14, \mathrm{p}$-value $=1.00)$. However, the statistically meaningful result was only obtained in livestock or fishery dominated areas, where the likelihood of obtaining negative results were almost 10 times higher than those for positive outcomes (odds ratio $=9.91, \mathrm{p}$-value $=0.06)$.

As for the social outcomes of urbanization, we observed a lower proportion of negative outcomes compared to positive outcomes for all areas, except livestock or fishery dominated areas (Fig. 7). However, these results were not statistically significant.

\section{DISCUSSION}

\section{General trends regarding outcomes of urbanization}

Urbanization develops much more dynamically in the Global South than in the Global North (Seto et al. 2011). Our review confirmed that not only the manifestations of urbanization but also the research agendas taken to study urbanization differ between the Global South and North, as supported by Nagendra et al. (2018). Ecology-related agendas were studied frequently in the North, whereas social ones were predominantly prioritized in the South, focusing on issues such as farmers' livelihoods or equity.

Ecological variables were generally reported with more frequent negative outcomes than social variables. Water quality was the variable with the highest share of negative ecological outcomes and was intensively substantiated in the scientific literature. Impervious surfaces in cities limit water infiltration and increase the depth of surface runoff (Long et al. 2014). Urban runoffwater often carries elevated levels of pollutants that contaminate landscapes (Cadenasso et al. 2008) and the food chain, consequently affecting human health. In the Global South, e.g., in Ghana (Amoah et al. 2005), Burkina Faso (Dao et al. 2018), and Pakistan (Bashir et al. 2018), farmers sometimes are bound to irrigate their crops with contaminated water, which spreads water-borne diseases. The risk of spreading such diseases is further increased by the congested housing in many urban areas (Seto and Pandey 2019).

Our finding of largely negative urbanization outcomes on soil fertility and the control of soil erosion is supported by Zhang et al. (2011). Frequently, replacing greenspaces by grey spaces aggravates soil erosion (Van Hengstum et al. 2007). However, in Inner Mongolia, urbanization decreased both water and wind erosion because people shifting to non-farming activities reduced soil disturbance (Wang et al. 2018). In some other cases, urbanization can promote soil fertility with a planned process of collecting and decomposing biodegradable soil wastes to composts for distribution across farms. Such management might also foster job options and food security for urban dwellers (Mkwambisi et al. 2015).

In urban landscapes rather than rural landscapes, a higher number of the pollination outcomes of urbanization were positive, mainly because urban greenspaces, with an abundance of both native and non-native flowering plants, offered more diverse habitats and forage for different insect pollinators (Gren and Andersson 2018).
The increase in plant diversity was related to a higher income level but was limited to places with a lower degree of urbanization. With higher degrees of urbanity, plant diversity decreased (Chamberlain et al. 2019), which could have implications on the abundance of pollinators. However, sometimes the risk of pests and invasion come along with the introduction of non-native plants in the name of enhancing plant diversity. For instance, an outbreak of the citrus canker damaged both ornamental gardening and the citrus industry in urban areas of Florida and took over 20 years to be eradicated (Gottwald et al. 2001).

As for social outcomes, our review identified more positive than negative outcomes. This could be expected because infrastructural development during urbanization frequently increases employment options and the income level of people (Arouri et al. 2017). However, these gains could be inequitably distributed (Balakrishnan 2013, Song et al. 2018). These inequalities were related to the phenomenon of occupation transition; peasants faced difficulties in finding fair employment following urbanization because of their limited education or skill level as compared to city dwellers, making peasants vulnerable to unemployment. However, urbanization improved agricultural commercialization (Siciliano 2012) and farmers' access to (new) markets (Otieno et al. 2009). For example, market access following transportation corridor development during urban expansion fostered regional equity between northern and southern regions of Uganda (Dorosh and Thurlow 2012).

There were conflicts among the negative social outcomes of urbanization, for example, between farmers and governments about compensation for farmland conversion to urban infrastructures in Shanghai in China (Song et al. 2018) and southern India (Balakrishnan 2013). Conflicts also arose in relation to livestock raising in and around urban areas. The odor from livestock and their manure often caused a conflict between farmers and residents (Liffmann et al. 2000). Conflicts might also occur among farmers of different age groups about perceived impoverishment of values and societal norms through urbanization and modernization (Slemp et al. 2012).

Our review indicated that increased food security was not among the positive outcomes of urbanization. Farmers' out-migration to urban areas and involvement in off-farm activities increased dependency on non-farm income sources, which may reinforce vulnerability toward food insecurity, especially for the urban poor (Satterthwaite et al. 2010). However, the outcomes on food security were context-dependent, without a clear global pattern depicting positive or negative outcomes. This review demonstrated that urbanization had more negative than positive outcomes on the cultural identity of farming systems, as illustrated by the cases of intensive market-oriented rice monoculture in the low lands of urban areas in the Philippines and Vietnam, which shifted away from traditional subsistence integrated farming systems in rural areas (Tekken et al. 2017). Overall, the general trend of these outcomes seems to be case dependent.

\section{Distribution of outcomes}

Urbanization outcomes differed across continents. Most of the positive social outcomes were recorded for Asia and Africa, mainly because, in these continents, agriculture in urban and periurban regions offers important opportunities for food security, 
especially in West Africa (Karg and Drechsel 2018). In North America, despite a long history of designing urban green infrastructure (Ahern 2007), many cases of negative ecological urbanization outcomes were reported. Here, spatial planning is less developed than in Europe, with intensive urban sprawl being a consequence (Barrington-Leigh and Millard-Ball 2015). Many positive ecological outcomes were reported in Europe, possibly because many European cities are actively promoting biocultural diversity (Elands et al. 2015), especially when compared to an increasingly ecologically impoverished countryside (Zasada 2011).

Our review further indicated that poorer and smaller cities reported relatively more frequent negative ecological outcomes, whereas megacities were related to higher positive ecological outcomes of urbanization (Fig. 5). In larger and wealthier cities, the higher proportion of green infrastructures resulted in a higher abundance of plant species, thus promoting pollination (in New York; Aronson et al. 2007) or soil erosion control (in Shandong; Lu et al. 2015). Such positive correlations between income and ecological outcomes in an urban context are often explored by the environmental Kuznets curve. Studies based on this curve often demonstrate that income level and ecological degradation are positively associated in low-income countries but negatively associated with an increase in income or in high-income countries (Mosconi et al. 2020). With the rise in income level in both situations, inequity or gentrification of neighborhoods could be reproduced (Schell et al. 2020). The relatively higher share of positive ecological outcomes in Europe could confirm the environmental Kuznets curve.

National wealth and positive social outcomes of urbanization were often inversely associated, as higher positive social outcomes for urbanization were reported in poorer rather than wealthier countries. As supported by the findings of Nguyen et al. (2016) in Vietnam and Wenban-Smith et al. (2016) in Tanzania, urbanization frequently offers poor farmers an opportunity to raise their income level by providing options of urban and periurban farming, as well as off-farm activities in cities or in the hinterlands. However, the income distribution of those activities may not be equitable. In the long run, our results confirmed that urbanization often leads to higher income inequalities (Liddle 2017).

Different dominant farming systems respond differently to urbanization. Livestock or fishery systems seemed to be most affected by urbanization, with a particularly high proportion of negative ecological outcomes. This finding was confirmed both in poor (Hazari and Kumar 2003) and wealthy urban contexts (Liffmann et al. 2000). In contrast, studies on perennial cropping systems, e.g., those centered around wine production in the Oplenac region of Serbia (Perovic et al. 2018) and deciduous fruit trees in New York (Aronson et al. 2007), revealed more positive than negative outcomes among both social variables. These farming systems seem better adapted to urban settings because of characteristics such as lower labor demand and improved market access.

Our results indicated that urbanization might offer benefits in terms of income options and health and education, most likely because of the capitalization of economies of scale. Such improved well-being seems to be translated into reduced human fertility and mortality rates (Beauchemin and Bocquier 2004). This finding may also be influenced by the fact that most migrants from rural areas were young or middle-aged, whereas elderly farmers often remained in rural areas (Song et al. 2018), highlighting the demographic instability between rural and urban areas.

\section{Policy implications}

Because urbanization can express itself in positive and negative outcomes in regional farming systems, efforts should be made to increase the positive and mitigate the negative outcomes when building sustainable cities and communities. One way of doing so is to better connect rural and urban people and enterprises and to enhance regional farming systems sustainably by recognizing the capacity of the farmers (Satterthwaite et al. 2010) to feed people in the region equitably and sustainably. Because urbanization mostly concentrates and centralizes economic value, matter, energy, and people at the center of the modern urban lifestyle (Barthel et al. 2019), inclusive urban policies should be promoted to foster equity among core city dwellers and peri- or ex-urban dwellers.

Our finding of significantly high negative ecological outcomes indicates a clear need for spatial planning policies that specifically address the ecological impacts of urban expansion on farmlands. For example, restoration and conservation policies should explicitly consider the specifications of productive farmland in urban and peri-urban environments, particularly fostering soil fertility, control of soil erosion, and carbon sequestration, thus maintaining productive agriculture and food security under conditions of urbanization (Barthel et al. 2019).

A particularly promising intervention pathway to enhance positive ecological outcomes of urbanization may be UGI planning, here understood as "a strategic planning approach that aims to develop networks of green and blue spaces in urban areas, designed and managed to deliver a wide range of ecosystem services and other benefits at all spatial scales" (Hansen et al. 2017:3). UGI planning can effectively foster biodiversity conservation, climate change adaptation, a green economy, and social cohesion by providing multiple nature-based solutions (Raymond et al. 2017). UGI planning is based on four principles: integration (of green and grey infrastructures), connectivity (between green/blue spaces and surroundings), multifunctionality (of ecosystem services), and social inclusion (during design, development, and implementation; Rolf et al. 2020). However, farmlands have rarely been considered in UGI strategies. The integration of farming components, such as orchards, grazing lands, (peri-)urban farmlands, and retention ponds, in a catchment area of urban green infrastructures to UGI planning may have the potential to control soil erosion and flood events, promote habitats and connectivity for plant and animal populations, enhance water quality, and foster food security. Future research on the implications of such an integrated approach are needed to better inform urban policies. When codesigned with researchers, practitioners, policy makers, and relevant stakeholders, farming components, such as green infrastructures, can offer integrated and cost-efficient solutions to coupled ecological and social challenges in urban and landscape planning. Such a strategy would enhance urban food production, nature protection, and environmental justice in urban and nearby areas. 


\section{Future research avenues}

Our review of the scientific literature was comprehensive, but it showed that there are substantial evidence gaps. First, although urbanization facilitates synergies and trade-offs among multiple social and ecological values, only a small number of such interactions among outcome variables have been investigated in our sample. Some studies pointed to interlinkages, for instance, between water pollution in urban runoffs and the spread of waterborne diseases in countries, such as Ghana (Amoah et al. 2005), Burkina Faso (Dao et al. 2018), and Pakistan (Bashir et al. 2018). Another example is a study of how inequity increased with increased income levels in urban landscapes in consequence of limited education and income-generating skills of rural dwellers in China (Song et al. 2018). Ecological synergies were investigated, for example, related to pollination and plant diversity in Berlin (Hausmann et al. 2016). These examples of synergy and tradeoffs are case-specific and reveal a need to explore the interactions more systematically between social and ecological variables. Additionally, existing studies are typically limited to assessing interactions between two or three different variables, and there is a need that future studies consider a broad set of ecological and social variables, addressing for example all (or most) of the 17 Sustainable Development Goals. Second, information on vast regions of North Africa, Russia, and Central Asia is missing, and we found only a relatively small number of studies from Oceania and South America. Thus, more research is needed in these regions to understand the impacts of urbanization on farming systems. Third, this review reported a smaller number of ecological outcomes in comparison to social outcomes. Future research needs to cover the ecological aspects of urbanization more comprehensively.

\section{CONCLUSION}

Urbanization is a major phenomenon of global change that sparks multiple sustainability outcomes. Urbanization and farming systems are in competition for land because urbanization mostly occurs at peri- or ex-urban landscapes. As for our results, our synthesis identified that water quality, soil fertility, and control of invasive species were major negative ecological outcomes. Pollination seems to be promoted in urban landscapes, as most cases of pollination reported positive outcomes. Regarding social outcomes, demographic stability and cultural identity were identified as particularly pressing issues. Social outcomes of urbanization related to the economic viability of farming and employment were often positive. Among the potential explanatory variables, negative ecological outcomes of urbanization most frequently occurred in the Global South, in medium-large cities, in poor countries, and in regions where livestock or fishery systems were dominant. Social outcomes were more frequently negative in the Americas, in large and megacities, in wealthy countries, and in areas with predominant livestock or fishery systems, and positive in poor countries. With these results, our global review of the ecological and social outcomes of urbanization on regional farming systems offers some key lessons. Most notably, it shows that urbanization is a complex socialecological process that affects regional farming systems in both positive and negative ways. Overall, our synthesis suggests that negative outcomes of urbanization on farming systems outnumber the positive ones, highlighting that urbanization overwhelmingly acts as a pressure on regional farming systems.
Responses to this article can be read online at: https://www.ecologyandsociety.org/issues/responses. $\mathrm{php} / 12579$

\section{Acknowledgments:}

We are grateful to the participants of the doctoral seminar organized by the Department of Agricultural Economics and Rural Development at Goettingen University and in particular to discussant Ellen Hoffmann for constructive feedback on the manuscript. We also highly appreciate the constructive feedback on the manuscript from Dr. Rijan Tamrakar, Dr. Thomas Krikser, Ms. Malin Tiebel, and Dr. Emmeline Topp. This research is funded by the Deutsche Forschungsgemeinschaft (DFG, German Research Foundation): project number 279374797.

\section{Data Availability:}

The datalcode that support the findings of this study are openly available through Zenodo at https://dx.doi.org/10.5281/zenodo.5342520.

\section{LITERATURE CITED}

Abu-hashim, M., M. Elsayed, and A. E. A. Belal. 2016. Effect of land-use changes and site variables on surface soil organic carbon pool at Mediterranean Region. Journal of African Earth Sciences 114:78-84. https://doi.org/10.1016/j.jafrearsci.2015.11.020

Ahern, J. 2007. Green infrastructure for cities: the spatial dimension. Pages 267-283 in V. Novotny and P. Brown, editors. Cities of the future: towards integrated sustainable water and landscape management. IWA Publishing, London, UK. [online] URL: https://people.umass.edu/jfa/pdf/Chapter17 Ahern2\%20copy. pdf

Amoah, P., P. Drechsel, and R. C. Abaidoo. 2005. Irrigated urban vegetable production in Ghana: sources of pathogen contamination and health risk elimination. Irrigation and Drainage 54(S1):S49-S61. https://doi.org/10.1002/ird.185

Arivarasi, R., and M. Ganesan. 2017. Seasonal variation in ground water quality and its suitability for drinking and agriculture: a case study in Kancheepuram region, Tamil Nadu, India. Global NEST Journal 19(1):131-139. https://journal.gnest. org/publication/gnest 01660

Aronson, M. F. J., S. N. Handel, and S. E. Clemants. 2007. Fruit type, life form and origin determine the success of woody plant invaders in an urban landscape. Biological Invasions 9 (4):465-475. https://doi.org/10.1007/s10530-006-9053-1

Arouri, M., A. B. Youssef, and C. Nguyen. 2017. Does urbanization reduce rural poverty? Evidence from Vietnam. Economic Modelling 60:253-270. https://doi.org/10.1016/j. econmod.2016.09.022

Balakrishnan, S. 2013. Highway urbanization and land conflicts: the challenges to decentralization in India. Pacific Affairs 86 (4):785-811. https://doi.org/10.5509/2013864785 
Barrington-Leigh, C., and A. Millard-Ball. 2015. A century of sprawl in the United States. Proceedings of the National Academy of Sciences of the United States of America 112(27):8244-8249. https://doi.org/10.1073/pnas.1504033112

Barthel, S., C. Isendahl, B. N. Vis, A. Drescher, D. L. Evans, and A. van Timmeren. 2019. Global urbanization and food production in direct competition for land: leverage places to mitigate impacts on SDG2 and on the Earth System. Anthropocene Review 6(1-2):71-97. https://doi.org/10.1177/205$\underline{3019619856672}$

Bashir, M. K., M. Ashfaq, M. K. Sharif, and G. Ali. 2018. Food safety perceptions vs reality: the case of peri-urban areas of Rawalpindi, Pakistan. Journal of Animal and Plant Sciences 28 (4):1128-1141.

Beauchemin, C., and P. Bocquier. 2004. Migration and urbanisation in francophone West Africa: an overview of the recent empirical evidence. Urban Studies 41(11):2245-2272. https://doi.org/10.1080/0042098042000268447

Bower, K. M. 2003. When to use Fisher's Exact Test. Six Sigma Forum Magazine 2(4):35-37. [online] URL: http://rube.asq.org/ pub/sixsigma/past/vol2 issue4/bower.html

Bren d'Amour, C., F. Reitsma, G. Baiocchi, S. Barthel, B. Güneralp, K. H. Erb, H. Haberl, F. Creutzig, and K. C. Seto. 2017. Future urban land expansion and implications for global croplands. Proceedings of the National Academy of Sciences of the United States of America 114(34):8939-8944. https://doi. org/10.1073/pnas.1606036114

Busck, A. G., S. P. Kristensen, S. Præstholm, A. Reenberg, and J. Primdahl. 2006. Land system changes in the context of urbanisation: examples from the peri-urban area of Greater Copenhagen. Geografisk Tidsskrift: Danish Journal of Geography 106(2):21-34. https://doi.org/10.1080/00167223.2006.10649554

Cadenasso, M. L., S. T. A. Pickett, P. M. Groffman, L. E. Band, G. S. Brush, M. F. Galvin, J. M. Grove, G. Hagar, V. Marshall, B. P. McGrath, J. P. M. O’Neil-Dunne, W. P. Stack, and A. R. Troy. 2008. Exchanges across land-water-scape boundaries in urban systems: strategies for reducing nitrate pollution. Annals of the New York Academy of Sciences 1134(1):213-232. https://doi. org/10.1196/annals.1439.012

Chamberlain, D. E., D. A. W. Henry, C. Reynolds, E. Caprio, and A. Amar. 2019. The relationship between wealth and biodiversity: a test of the luxury effect on bird species richness in the developing world. Global Change Biology 25(9):3045-3055. https://doi. org/10.1111/gcb.14682

Cohen, J. 1960. A coefficient of agreement for nominal scales. Educational and Psychological Measurement 20(1):37-46. https://doi.org/10.1177/001316446002000104

Cugurullo, F. 2016. Speed kills: fast urbanism and endangered sustainability in the Masdar City project. Pages 78-92 in A. Datta and A. Shaban, editors. Mega-urbanization in the Global South: fast cities and new urban utopias of the postcolonial state. Routledge, London, UK.

Dao, J., K. Stenchly, O. Traore, P. Amoah, and A. Buerkert. 2018. Effects of water quality and post-harvest handling on microbiological contamination of lettuce at urban and peri-urban locations of Ouagadougou, Burkina Faso. Foods 7(12):206. https://doi.org/10.3390/foods7120206

Davis, J. C., and J. V. Henderson. 2003. Evidence on the political economy of the urbanization process. Journal of Urban Economics 53(1):98-125. https://doi.org/10.1016/S0094-1190(02) $\underline{00504-1}$

Davivongs, V., M. Yokohari, and Y. Hara. 2012. Neglected canals: deterioration of indigenous irrigation system by urbanization in the west peri-urban area of Bangkok Metropolitan Region. Water 4(1):12-27. https://doi.org/10.3390/w4010012

Derkzen, M. L., H. Nagendra, A. J. A. Van Teeffelen, A. Purushotham, and P. H. Verburg. 2017. Shifts in ecosystem services in deprived urban areas: understanding people's responses and consequences for well-being. Ecology and Society 22(1):51. https://doi.org/10.5751/ES-09168-220151

Dorosh, P., and J. Thurlow. 2012. Agglomeration, growth and regional equity: an analysis of agriculture-versus urban-led development in Uganda. Journal of African Economies 21 (1):94-123. https://doi.org/10.1093/jae/ejr033

Elands, B. H. M., K. F. Wiersum, A. E. Buijs, and K. Vierikko. 2015. Policy interpretations and manifestation of biocultural diversity in urbanized Europe: conservation of lived biodiversity. Biodiversity and Conservation 24(13):3347-3366. https://doi. org/10.1007/s10531-015-0985-6

Fetzer, T., and A. Shanghavi. 2015. On the political economy of urbanization: evidence from Africa. Mimeo.

Food and Agriculture Organization of the United Nations (FAO). 2006. Food security. Policy Brief 2. FAO Agriculture and Development Economics Division, Rome, Italy. [online] URL: http://www.fao.org/fileadmin/templates/faoitaly/documents/pdf/ pdf Food Security Cocept Note.pdf

Geist, H. J., and E. F. Lambin. 2002. Proximate causes and underlying driving forces of tropical deforestation. BioScience 52 (2):143-150. https://doi.org/10.1641/0006-3568(2002)052[0143: PCAUDF]2.0.CO;2

Gottwald, T. R., G. Hughes, J. H. Graham, X. Sun, and T. Riley. 2001. The citrus canker epidemic in Florida: the scientific basis of regulatory eradication policy for an invasive species. Phytopathology 91(1):30-34. https://doi.org/10.1094/PHYTO.2001.91.1.30

Gren, A., and E. Andersson. 2018. Being efficient and green by rethinking the urban-rural divide: combining urban expansion and food production by integrating an ecosystem service perspective into urban planning. Sustainable Cities and Society 40:75-82. https://doi.org/10.1016/j.scs.2018.02.031

Hansen, R., E. Rall, E. Chapman, W. Rolf, S. Pauleit. 2017. Urban green infrastructure planning: a guide for practitioners. Green Surge, Munich, Germany. [online] URL: https://www. researchgate.net/publication/319967102 Urban Green Infrastructure Planning_A_Guide for_Practitioners

Hatab, A. A., M. E. R. Cavinato, and C. J. Lagerkvist. 2019. Urbanization, livestock systems and food security in developing countries: a systematic review of the literature. Food Security 11 (2):279-299. https://doi.org/10.1007/s12571-019-00906-1 
Hausmann, S. L., J. S. Petermann, and J. Rolff. 2016. Wild bees as pollinators of city trees. Insect Conservation and Diversity 9 (2):97-107. https://doi.org/10.1111/icad.12145

Hazari, B. R., and A. Kumar. 2003. Caste, land and livestock holdings in India: an analysis. International Forestry Review 5 (4):364-369. https://doi.org/10.1505/IFOR.5.4.364.22655

Hoffmann, E. M., M. Jose, N. Nölke, and T. Möckel. 2017. Construction and use of a simple index of urbanisation in the rural-urban interface of Bangalore, India. Sustainability 9 (11):2146. https://doi.org/10.3390/su9112146

Karg, H., and P. Drechsel, editors. 2018. Atlas of West African urban food systems: examples from Ghana and Burkina Faso. International Water Management Institute (IWMI), Colombo, Sri Lanka. https://doi.org/10.5337/2018.224

Karn, S. K., and H. Harada. 2001. Surface water pollution in three urban territories of Nepal, India, and Bangladesh. Environmental Management 28(4):483-496. https://doi.org/10.1007/ $\underline{\mathrm{s} 002670010238}$

Liddle, B. 2017. Urbanization and inequality/poverty. Urban Science 1(4):35. https://doi.org/10.3390/urbansci1040035

Liffmann, R. H., L. Huntsinger, and L. C. Forero. 2000. To ranch or not to ranch: home on the urban range? Journal of Range Management 53(4):362-370. https://doi.org/10.2307/4003745

Long, H., Y. Liu, X. Hou, T. Li, and Y. Li. 2014. Effects of land use transitions due to rapid urbanization on ecosystem services: implications for urban planning in the new developing area of China. Habitat International 44:536-544. https://doi.org/10.1016/ j.habitatint.2014.10.011

Lu, Q., Z. Gao, J. Ning, X. Bi, and Q. Wang. 2015. Impact of progressive urbanization and changing cropping systems on soil erosion and net primary production. Ecological Engineering 75:187-194. https://doi.org/10.1016/j.ecoleng.2014.11.048

Magliocca, N. R., T. K. Rudel, P. H. Verburg, W. J. McConnell, O. Mertz, K. Gerstner, A. Heinimann, and E. C. Ellis. 2015. Synthesis in land change science: methodological patterns, challenges, and guidelines. Regional Environmental Change 15 (2):211-226. https://doi.org/10.1007/s10113-014-0626-8

McGregor, S. E. 1976. Insect pollination of cultivated crop plants. Vol. 496. Agricultural Research Service, US Department of Agriculture, Washington, DC, USA.

Mder, P., A. Fliebach, D. Dubois, L. Gunst, P. Fried, and U. Niggli. 2002. Soil fertility and biodiversity in organic farming. Science 296(5573):1694-1697. https://doi.org/10.1126/science.1071148

Mkwambisi, D. D., A. J. Dougill, P. Antwi-Agyei, and C. P. Chabvuta. 2015. Urbanization and soil nutrient challenges and opportunities: lessons from Malawian cities. Pages 85-94 in F. Q. Brearley and A. D. Thomas, editors. Land-use change impacts on soil processes: tropical and savannah ecosystems. CABI International, Oxford, UK. https://doi.org/10.1079/9781780642109.0085

Moher, D., L. Shamseer, M. Clarke, D. Ghersi, A. Liberati, M. Petticrew, P. Shekelle, and L. A. Stewart. 2015. Preferred reporting items for systematic review and meta-analysis protocols
(PRISMA-P) 2015 statement. Systematic Reviews 4(1):1. https:// doi.org/10.1186/2046-4053-4-1

Mosconi, E. M., A. Colantoni, F. Gambella, E. Cudlinová, L. Salvati, and J. Rodrigo-Comino. 2020. Revisiting the environmental Kuznets curve: the spatial interaction between economy and territory. Economies 8(3):74. https://doi. org/10.3390/economies8030074

Nagendra, H., X. Bai, E. S. Brondizio, and S. Lwasa. 2018. The urban south and the predicament of global sustainability. Nature Sustainability 1:341-349. https://doi.org/10.1038/s41893-018-0101-5

Nguyen, T. H. T., V. T. Tran, Q. T. Bui, Q. H. Man, and T. de Vries Walter. 2016. Socio-economic effects of agricultural land conversion for urban development: case study of Hanoi, Vietnam. Land Use Policy 54:583-592. https://doi.org/10.1016/j. landusepol.2016.02.032

Opitz, I., R. Berges, A. Piorr, and T. Krikser. 2016. Contributing to food security in urban areas: differences between urban agriculture and peri-urban agriculture in the Global North. Agriculture and Human Values 33(2):341-358. https://doi. org/10.1007/s10460-015-9610-2

Otieno, D. J., J. Omiti, T. Nyanamba, and E. McCullough. 2009. Market participation by vegetable farmers in Kenya: a comparison of rural and peri-urban areas. African Journal of Agricultural Research 4(5):451-460. https://doi.org/10.5897/ AJAR.9000483

Patel, N., and A. K. Kathwas. 2012. Assessment of spatiotemporal dynamics of soil erosional severity through geoinformatics. Geocarto International 27(1):3-16. https://doi. org/10.1080/10106049.2011.614359

Perović, V., D. Jakšić, D. Jaramaz, N. Koković, D. Čakmak, M. Mitrović, and P. Pavlović. 2018. Spatio-temporal analysis of land use/land cover change and its effects on soil erosion (case study in the Oplenac wine-producing area, Serbia). Environmental Monitoring and Assessment 190:675. https://doi.org/10.1007/ s10661-018-7025-4

Petrick, M., and P. Zier. 2012. Common Agricultural Policy effects on dynamic labour use in agriculture. Food Policy 37(6):671-678. https://doi.org/10.1016/j.foodpol.2012.07.004

Plieninger, T., H. Draux, N. Fagerholm, C. Bieling, M. Bürgi, T. Kizos, T. Kuemmerle, J. Primdahl, and P. H. Verburg. 2016. The driving forces of landscape change in Europe: a systematic review of the evidence. Land Use Policy 57:204-214. https://doi. org/10.1016/j.landusepol.2016.04.040

Primdahl, J., E. Andersen, S. Swaffield, and L. Kristensen. 2013. Intersecting dynamics of agricultural structural change and urbanisation within European rural landscapes: change patterns and policy implications. Landscape Research 38(6):799-817. https://doi.org/10.1080/01426397.2013.772959

Pullin, A. S., and T. M. Knight. 2009. Doing more good than harm: building an evidence-base for conservation and environmental management. Biological Conservation 142 (5):931-934. https://doi.org/10.1016/j.biocon.2009.01.010 
Rao, E. J. O., and M. Qaim. 2011. Supermarkets, farm household income, and poverty: insights from Kenya. World Development 39(5):784-796. https://doi.org/10.1016/j.worlddev.2010.09.005

Raymond, C. M., N. Frantzeskaki, N. Kabisch, P. Berry, M. Breil, M. R. Nita, D. Geneletti, and C. Calfapietra. 2017. A framework for assessing and implementing the co-benefits of nature-based solutions in urban areas. Environmental Science and Policy 77:15-24. https://doi.org/10.1016/j.envsci.2017.07.008

Rolf, W., K. Diehl, I. Zasada, and H. Wiggering. 2020. Integrating farmland in urban green infrastructure planning: an evidence synthesis for informed policymaking. Land Use Policy 99:104823. https://doi.org/10.1016/j.landusepol.2020.104823

Satterthwaite, D., G. McGranahan, and C. Tacoli. 2010. Urbanization and its implications for food and farming. Philosophical Transactions of the Royal Society B: Biological Sciences 365(1554):2809-2820. https://doi.org/10.1098/rstb.2010.0136

Schell, C. J., K. Dyson, T. L. Fuentes, S. Des Roches, N. C. Harris, D. S. Miller, C. A. Woelfle-Erskine, and M. R. Lambert. 2020. The ecological and evolutionary consequences of systemic racism in urban environments. Science 369(6510):1-19. https://doi. org/10.1126/science.aay4497

Sen, S. 2017. Neo-liberal urbanization, work participation and women: comparing the urban and peri-urban contexts of Delhi with Mumbai and Kolkata. Pages 129-151 S. S. Acharya, S. Sen, M. Punia, and S. Reddy, editors. Marginalization in globalizing Delhi: issues of land, livelihoods and health. Springer, New Delhi, India.

Seto, K. C., M. Fragkias, B. Güneralp, and M. K. Reilly. 2011. A meta-analysis of global urban land expansion. PLoS ONE 6(8): e23777. https://doi.org/10.1371/journal.pone.0023777

Seto, K. C., and B. Pandey. 2019. Commentary urban land use: central to building a sustainable future. One Earth 1(2):168-170. https://doi.org/10.1016/j.oneear.2019.10.002

Seto, K. C., and N. Ramankutty. 2016. Hidden linkages between urbanization and food systems. Science 352(6288):943-945. https://doi.org/10.1126/science.aaf7439

Seto, K. C., and A. Reenberg, editors. 2014. Rethinking global land use in an urban era. MIT Press, Cambridge, Massachusetts, USA.

Siciliano, G. 2012. Urbanization strategies, rural development and land use changes in China: a multiple-level integrated assessment. Land Use Policy 29(1):165-178. https://doi. org/10.1016/j.landusepol.2011.06.003

Slemp, C., M. A. Davenport, E. Seekamp, J. M. Brehm, J. E. Schoonover, and K. W. J. Williard. 2012. "Growing too fast": local stakeholders speak out about growth and its consequences for community well-being in the urban-rural interface. Landscape and Urban Planning 106(2):139-148. https://doi.org/10.1016/j. landurbplan.2012.02.017

Song, J., H. Du, and S. Li. 2018. Smooth or troubled occupation transition? Urbanization and employment of former peasants in Western China. China Review 18 (1):79-105. [online] URL: https://www.jstor.org/stable/26435635
Su, S., X. Ma, and R. Xiao. 2014. Agricultural landscape pattern changes in response to urbanization at ecoregional scale. Ecological Indicators 40:10-18. https://doi.org/10.1016/j. ecolind.2013.12.013

Tacoli, C. 2017. Why small towns matter: urbanization, rural transformations and food security. International Institute for Environment and Development (IIED), London, UK. [online] URL: https://pubs.iied.org/sites/default/files/pdfs/migrate/10815IIED. pdf

Tekken, V., J. H. Spangenberg, B. Burkhard, M. Escalada, S. StollKleemann, D. T. Truong, and J. Settele. 2017. "Things are different now": farmer perceptions of cultural ecosystem services of traditional rice landscapes in Vietnam and the Philippines. Ecosystem Services 25:153-166. https://doi.org/10.1016/j. ecoser.2017.04.010

Tong, W., P. Zhang, K. Lo, T. Chen, and R. Gao. 2017. Agedifferentiated impact of land appropriation and resettlement on landless farmers: a case study of Xinghua village, China. Geographical Research 55(3):293-304. https://doi.

org/10.1111/1745-5871.12208

Townsend-Small, A., and C. I. Czimczik. 2010. Carbon sequestration and greenhouse gas emissions in urban turf. Geophysical Research Letters 37(2). https://doi.org/10.1029/2009GL041675

Turner, M. D. 2004. Political ecology and the moral dimensions of "resource conflicts": the case of farmer-herder conflicts in the Sahel. Political Geography 23(7):863-889. https://doi.org/10.1016/ j.polgeo.2004.05.009

United Nations. 2014. World's population increasingly urban with more than half living in urban areas. United Nations, New York, New York, USA. [online] URL: http://www.un.org/en/ development/desa/news/population/world-urbanization-prospects-2014. html

United Nations. 2017. Goal 11: make cities inclusive, safe, resilient and sustainable. United Nations, New York, New York, USA. [online] URL: https://www.un.org/sustainabledevelopment/cities/

United Nations. 2018. World urbanization prospects: the 2018 revision (key facts). United Nations, New York, New York, USA. [online] URL: https://population.un.org/wup/Publications/Files/ WUP2018-KeyFacts.pdf

Uprety, L. P. 1970. Social equity in farmer-managed irrigation in the Terai of Nepal. Occasional Papers in Sociology and Anthropology 9:141-175. https://doi.org/10.3126/opsa.v9i0.1139

Van Hengstum, P. J., E. G. Reinhardt, J. I. Boyce, and C. Clark. 2007. Changing sedimentation patterns due to historical land-use change in Frenchman's Bay, Pickering, Canada: evidence from high-resolution textural analysis. Journal of Paleolimnology 37 (4):603-618. https://doi.org/10.1007/s10933-006-9057-y

Vang Rasmussen, L., B. Coolsaet, A. Martin, O. Mertz, U. Pascual, E. Corbera, N. Dawson, J. A. Fisher, P. Franks, and C. M. Ryan. 2018. Social-ecological outcomes of agricultural intensification. Nature Sustainability 1:275-282. https://doi. org/10.1038/s41893-018-0070-8 
van Vliet, J. 2019. Direct and indirect loss of natural area from urban expansion. Nature Sustainability 2(8):755-763. https://doi. org/10.1038/s41893-019-0340-0

van Vliet, J., N. R. Magliocca, B. Büchner, E. Cook, J. M. Rey Benayas, E. C. Ellis, A. Heinimann, E. Keys, T. M. Lee, J. Liu, O. Mertz, P. Meyfroidt, M. Moritz, C. Poeplau, B. E. Robinson, R. Seppelt, K. C. Seto, and P. H. Verburg. 2015. Meta-studies in land use science: current coverage and prospects. Ambio 45(1):15-28. https://doi.org/10.1007/s13280-015-0699-8

van Vliet, N., O. Mertz, A. Heinimann, T. Langanke, U. Pascual, B. Schmook, C. Adams, D. Schmidt-Vogt, P. Messerli, S. Leisz, J. C. Castella, L. Jørgensen, T. Birch-Thomsen, C. Hett, T. B. Bruun, A. Ickowitz, K. C. Vu, K. Yasuyuki, J. Fox, C. Padoch, W. Dressler, and A. D. Ziegler. 2012. Trends, drivers and impacts of changes in swidden cultivation in tropical forest-agriculture frontiers: a global assessment. Global Environmental Change 22 (2):418-429. https://doi.org/10.1016/j.gloenvcha.2011.10.009

Wang, L. Y., Y. Xiao, E. M. Rao, L. Jiang, Y. Xiao, and Z. Y. Ouyang. 2018. An assessment of the impact of urbanization on soil erosion in Inner Mongolia. International Journal of Environmental Research and Public Health 15(3):550. https://doi. org/10.3390/ijerph15030550

Wenban-Smith, H., A. Fasse, and U. Grote. 2016. Food security in Tanzania: the challenge of rapid urbanisation. Food Security 8(5):973-984. https://doi.org/10.1007/s12571-016-0612-8

Wood, B. A., H. T. Blair, D. I. Gray, P. D. Kemp, P. R. Kenyon, S. T. Morris, and A. M. Sewell. 2014. Agricultural science in the wild: a social network analysis of farmer knowledge exchange. PLoS ONE 9(8):e105203. https://doi.org/10.1371/journal. pone. 0105203

Wood, D., and J. M. Lenné, editors. 1999. Agrobiodiversity: characterization, utilization and management. CABI Publishing, Wallingford, UK.

Ye, Y., J. Zhang, B. A. Bryan, L. Gao, Z. Qin, L. Chen, and J. Yang. 2018. Impacts of rapid urbanization on ecosystem services along urban-rural gradients: a case study of the GuangzhouFoshan Metropolitan area, South China. Ecoscience 25 (3):235-247. https://doi.org/10.1080/11956860.2018.1442086

Zasada, I. 2011. Multifunctional peri-urban agriculture: a review of societal demands and the provision of goods and services by farming. Land Use Policy 28(4):639-648. https://doi.org/10.1016/ j.landusepol.2011.01.008

Zhai, C., W. Wang, X. He, W. Zhou, L. Xiao, and B. Zhang. 2017. Urbanization drives SOC accumulation, its temperature stability and turnover in forests, Northeastern China. Forests 8(4):1-18. https://doi.org/10.3390/f8040130

Zhang, J., L. Pu, B. Peng, and Z. Gao. 2011. The impact of urban land expansion on soil quality in rapidly urbanizing regions in China: Kunshan as a case study. Environmental Geochemistry and Health 33(2):125-135. https://doi.org/10.1007/s10653-010-9326-6

Zhou, Y., S. J. Smith, K. Zhao, M. Imhoff, A. Thomson, B. BondLamberty, G. R. Asrar, X. Zhang, C. He, and C. D. Elvidge. 2015. A global map of urban extent from nightlights. Environmental Research Letters 10(5):2000-2010. https://doi.org/10.1088/1748-9326/10/5/054011 